\title{
A re-analysis of the supposed role of lead poisoning in Sir John Franklin's last expedition, 1845-1848
}

\section{Keith Millar}

Institute of Mental Health, College of Medical, Veterinary and Life Sciences, University of Glasgow, Gartnavel Royal Hospital, Glasgow G12 0XH (keith.millar@glasgow.ac.uk)

\section{Adrian W. Bowman}

School of Mathematics and Statistics, University of Glasgow, University Gardens, Glasgow G12 8QW

\author{
William Battersby \\ Apartment 1511, Strata Building, London SE1 6EG \\ Received September 2013 ; first published online 7 January 2014
}

ABSTRACT. The 'Franklin expedition' of 1845 set out to establish a 'northwest passage' between the Atlantic and Pacific oceans but ended with the deaths of all 129 crewmen in the grimmest of circumstances. The hypothesis that lead poisoning may have contributed to the disaster is examined by re-analysis of the bone-lead content of seven skeletons in order to model statistically the likely variation in lead burden across the whole crew. Comparison of the estimated lead burdens with present-day data that associates lead with cognitive and physical morbidity suggests that a proportion of the crew may have experienced few or no adverse effects whilst those with higher burdens may have suffered some significant debility. It is unclear whether such debility would have been incapacitating or exceptional for the lead-contaminated environment of nineteenth-century Britain. Whilst lead alone may not have caused the disaster, it is proposed that high levels of lead may have interacted with other factors including dietary insufficiencies and individual constitutional differences to render some, but not all, of the crew more vulnerable to debility in the final throes of the expedition.

\section{Introduction}

The present study

The British 'Franklin expedition' of 1845 attempted to complete the final link in a 'northwest passage' between the Atlantic and Pacific oceans but ended in a catastrophe which claimed the lives of all 129 officers and men. Many factors contributed to the disaster (see Cyriax 1939; Lambert 2009; Owen 1978) but one of central current interest is the supposed role of lead poisoning. The analysis of skeletal and soft tissue samples from the crew's remains has revealed high levels of lead and provoked speculation that lead poisoning and its associated debility played a significant role in the failure of the expedition (Beattie and Geiger 1987). The present study conducts further analyses to determine whether there was interindividual variation between members of the crew in their accumulation of lead and thus in the degree of physical and mental debility suffered. The findings may have implications for the role of lead poisoning in the disaster.

\section{Historical background to the Franklin expedition}

The chronology of the Franklin expedition has been described in great detail by many authors (Brandt 2011; Cyriax 1939; Lambert 2009; Markham 1921) so that a summary of the most significant events will suffice here. On 19 May 1845 a Royal Naval expedition under the command of Captain Sir John Franklin departed from the Thames with the mission to gather scientific data on polar magnetic variation and establish a navigable northwest passage between the Atlantic and Pacific Oceans. The prospects for success were thought to be good: HMS Erebus and Terror had been strengthened, fitted with auxiliary steam power and provisioned for three years, and many of the crew had significant polar experience. The expedition was last seen in Baffin Bay in late July 1845 and reported to have been in good health and confident spirits (Cyriax 1939).

The absence of any further communication led to a series of searches which, due to miscalculation and illfortune, continued for eleven years before the expedition's fate became clear. In 1850, the expedition's winter quarters of 1845-1846 were discovered at Beechey Island, and three graves. In 1854, Inuit people told of encountering starving white men, and corpses, four years earlier on King William Island to the north of the Canadian mainland, although this chronology has been challenged. However, it was not until 1859 that one of the very few written records recovered from the expedition was found at Victory Point on King William Island and allowed a tentative reconstruction to be made of the progress of the expedition from 1845 to 1848 . The record, which had been written in May 1847 by Commander Fitzjames of the Erebus, indicated satisfactory progress and closed with the encouraging valedictory 'All Well'. However, in an addendum written 11 months later on 25 April 1848, Fitzjames revealed a marked reversal of fortune: the total deaths by then were 9 officers and 15 men, including Sir John Franklin who had died on 11 June 1847. The ships had just been deserted, having been beset 
in the ice in Victoria Strait northwest of King William Island since September 1846. A further brief addendum by Captain Crozier of the Terror, now senior officer of the expedition, stated 'and start on tomorrow $26^{\text {th }}$ for Backs Fish River', from which it has generally been assumed that the survivors intended to trek en masse to the Back River estuary on the Canadian mainland, and then to proceed to Hudson Bay Company outposts and safety.

The discovery of skeletal remains along the route indicated that many had died only $80 \mathrm{~km}$ from the last known position of the ships, and this was interpreted as evidence of great debility at that time (Cyriax 1939). Some returned to the ships and the time and circumstances of their deaths remain unclear (Woodman 1991). Some reached the mainland where they, too, perished. The ships' logs and other journals chronicling the events leading to the disaster would have been carried by the survivors but none has been recovered. It is known that some written records were found by the Inuit who discarded them as worthless (Woodman 1991: 89) or destroyed them for superstitious reasons (Eber 2008: 107). In the absence of other evidence, it was concluded that, with the provisions almost exhausted, the crew had no alternative but to abandon their ships and attempt an overland retreat that was beyond their capability; all were presumed to have died of starvation, scurvy and exposure (Cyriax 1939). The disaster remains the greatest single loss of life inflicted upon polar exploration.

\section{Contemporary background}

In the late twentieth century the cause of the disaster was put in a new light when high levels of lead in bone, soft tissue and hair samples were found in samples from the ice-preserved corpses in the graves on Beechey Island and from skeletal remains from King William Island (Amy and others 1986; Beattie 1985; Beattie and Geiger 1987; Beattie and Savelle 1983; Keenleyside and others 1996, 1997; Kowal and others 1989, 1991; Notman and others 1987). The discovery provoked speculation that lead poisoning might have played a role in the disaster, either directly or by exacerbating the effects of scurvy, starvation and other illnesses, and by affecting cognitive function.

From an analysis of lead isotopes, the source of the lead was concluded to be solder which had been copiously applied when sealing the expedition's canned provisions and had then contaminated the food (Kowal and others 1991). Farrer (1993) proposed a different interpretation of the isotope data and, with other evidence including widespread lead contamination in nineteenthcentury Britain, disputed whether the canned food was the source of the lead. Rather, Farrer (1993) and Battersby (2008) have noted that the expedition's drinking water was obtained by melting snow which would produce "soft" water having a plumbo-solvent effect upon the lead in supply pipes and tanks. Water supplies were a common source of lead ingestion in the nineteenth century on land and at sea (Curtin 1989; Troesken, 2007) and Battersby and Carney (2011) note that, whilst the plans of the Erebus and Terror do not state explicitly the composition of the tank and pipes in question, lead was commonly used for such purposes. Confirmation would be made by eventual discovery of the ships.

A counter to the hypothesis that significant lead poisoning occurred on the ships has arisen from a study concluding that the levels of bone lead did not increase during the expedition. Martin and others (2013) analysed bone-lead distribution and lead isotope distribution in bone samples from Beechey Island and King William Island. They confirmed the overall high lead burdens but concluded that the distribution and concentrations of lead within bone samples indicated long-term exposure prior to the expedition and that there was 'no evidence for a sudden massive increase in [lead] during the latter part of any individual's life' (Martin and others 2013: 27): in other words, that the crew embarked upon the expedition with existing high levels of lead. It should be noted that the analysis involved very small samples: for example, the lead distribution involved repeated measures from only two samples so that generalisation to the whole crew might be tenuous. Moreover, Mays (personal communication, 16 August 2013) has observed that the comparison of lead analyses from inner, middle and outer parts of long-bone sections is of unclear value for shedding light on the timing of lead uptake during an individual's life. Given the potential implications of Martin and others' conclusions for the 'lead-poisoning hypothesis', it would seem important to conduct further analyses to determine whether their conclusions can be supported.

Debate as to the source of the lead and the timeline of its supposed accumulation will continue, but the relatively high levels have not been called in doubt. The lead burdens might be consistent with the known widespread contamination by lead of the atmosphere, water, foodstuffs, tableware and drinking vessels in nineteenthcentury Britain (Beattie 1986; Farrer 1993; Hernberg 2000) so that, at the time of embarkation, the crew would have carried substantially greater lead burdens than those of today. However, as there are no known normative data for bone-lead levels in the nineteenth-century British population, far less for Royal Navy crews, it may be that the crew's lead burdens were typical for the time.

Whether typical or not, it is of interest to estimate whether those levels might have exerted an adverse effect upon the crew. It has long been known that individuals vary widely in their susceptibility to lead poisoning (Kosnett and others 2007; Milković-Kraus and others 1996; Watson 1857) so that there are grounds to consider whether all the crew need necessarily have been seriously affected. The potential effects are estimated below, first by reviewing the evidence for individual variation in lead burdens from the limited published evidence. A statistical procedure is then applied to estimate the likely variation in lead burden across the whole crew. Finally, the effects upon the crew are estimated by considering the implications of their lead burdens in light of 
neurobehavioural and physical morbidity in present-day, lead-exposed groups.

\section{Evidence of variability in lead burdens}

\section{The Beechey Island bodies}

The ice-preserved bodies of John Torrington (20 years), John Hartnell (25 years) and William Braine (33 years) in graves on Beechey Island were subjected to detailed forensic examination in a remarkable series of autopsies conducted in arduous conditions (Amy and others 1986; Beattie and Geiger 1987: Notman and others 1987). Their emaciated condition was taken to imply prolonged illness prior to death and would be consistent with the suspected evidence of tuberculosis (Amy and others 1986) that was common amongst nineteenth-century naval crews and the population in general. Most significantly, however, the examinations also revealed a high lead content in bone, soft tissue and hair. In an initial report, Torrington's body provided samples from a single rib, radius and clavicle having a range of lead content of $110-151 \mathrm{ppm}$ or $\mu \mathrm{gPb} / \mathrm{g}$ (contents of the individual bones were not published: Amy and others 1986). For unstated reasons, Torrington's clavicle was omitted from a subsequent publication (Kowal and others 1989: Table 1) which added bones from Hartnell and Braine to form a sample comprising a single radius (presumably from Torrington), femur, skull and vertebra, and two ribs (one, again presumably, from Torrington) and yielded a mean lead content of 128.3 $\mu \mathrm{gPb} / \mathrm{g}$ (SD $=45.0$; range 69-183). It was not stated which of the other bones were sampled from Hartnell and Braine respectively but, given the overall range when compared to that for Torrington alone, it may reasonably be concluded that the levels varied between the three men.

The analysis of soft tissue is of greater importance because it indicates more immediate lead exposure than the long-term accumulation reflected in bone. Levels of lead in the aorta and spleen were similar to those in present-day lead-exposed groups, but the levels in liver, kidney, stomach and skin were, relatively, very high and would imply recent exposure (Kowal and others 1991: Table 2). Regrettably, individual data for the three men were not published, nor the standard deviation or range, thus leaving it unclear whether the published values were means or single values, and thus whether all three bodies contributed data for each organ. It is therefore unclear whether all the men had accumulated similar levels of lead in their soft tissues or whether, as in the case of bone and hair (see below), they showed large inter-individual differences.

Differences between the three men in lead accumulation are clearly evident in the analysis by Kowal and others (1989) of hair that was sampled in $1 \mathrm{~cm}$ segments from $10 \mathrm{~cm}$ hairs taken from the nape (that is 10 samples from each hair). Whilst it is important to consider the implications of the hair analysis, it has been noted that many factors seriously affect the reliability of hair as a biomarker of lead exposure (Barbosa and others 2005; Kowal and others 1991; Rodrigues and others 2008). As hair grows at approximately $1.1 \mathrm{~cm}$ per month (Kowal and others 1991), the $10 \mathrm{~cm}$ length equates to some eight to nine months of growth which, in the case of Torrington and Hartnell, conveniently encompasses their time from departure in May 1845 until their deaths in the first week of January 1846 . The segment of root at the nape was indicative of lead exposure in the four to eight weeks prior to death. The mean levels (SD: range) and the levels in the root segments were: Torrington $565 \mu \mathrm{gPb} / \mathrm{g}$ (117 $\mu \mathrm{gPb} / \mathrm{g}: 330-707 \mu \mathrm{gPb} / \mathrm{g}$ ) and $330 \mu \mathrm{gPb} / \mathrm{g}$; Hartnell $326 \mu \mathrm{gPb} / \mathrm{g}(110 \mu \mathrm{gPb} / \mathrm{g}: 222-510 \mu \mathrm{gPb} / \mathrm{g})$ and $265 \mu \mathrm{gPb} / \mathrm{g}$; Braine $225 \mu \mathrm{gPb} / \mathrm{g}$ (90 $\mu \mathrm{gPb} / \mathrm{g}$ : 158-317 $\mu \mathrm{gPb} / \mathrm{g}$ ) and $211 \mu \mathrm{gPb} / \mathrm{g}$ (from Kowal and others 1989: Table 6). Thus, the means for Hartnell and Braine (both of Erebus) were $42 \%$ and $60 \%$ lower, respectively, than that of Torrington (of Terror). The difference in means could be explained if the domestic economies of the two ships exposed their companies to different levels of lead contamination, or it might be a consequence of each individual's propensity to accumulate lead, or to some unknown factor. Whilst the range of lead content and the level in the $1 \mathrm{~cm}$ sample at the root were published for each man, it is regrettable that the lead contents of the other nine $1 \mathrm{~cm}$ sections were not published as they would have provided an excellent time-line of change in hair-lead content over the eight-month period.

Torrington's hair also provides evidence of a high lead content at the time of joining the expedition. The root segment had a content of $330 \mu \mathrm{gPb} / \mathrm{g}$ and, as the lowest value of the range was precisely $330 \mu \mathrm{gPb} / \mathrm{g}$, it can be assumed the root was the lowest value in the range. Logically, therefore, the most distal segment of his $10 \mathrm{~cm}$ hair sample (which at the time of departure was growing at the nape and whose lead content therefore indicated exposure both prior to, and at the time of, departure) must have had a lead content that at least equalled, and most probably exceeded, $330 \mu \mathrm{gPb} / \mathrm{g}$. As the concentration of trace elements in the root segment lags the blood-lead level by approximately 20 days (Clarkson and Magos 2006), the implication is then that Torrington had already accumulated high levels of lead at the time of departure. Moreover, given that 'only over the last inch or so [that is the $1 \mathrm{~cm}$ root segment] did the level [of lead in Torrington's hair] drop (Beattie and Geiger 1987: 194), the figures above would imply that the levels in his hair were high over the eight-month period from embarkation.

If so, it is unclear what sustained those high levels in the first two or three months when the supposed leadcontaminated tinned provisions were little used, if at all (Farrer 1993), and where snow was not being melted to produce drinking water having a plumbo-solvent effect on lead supply pipes. Certainly, Torrington's duties as stoker on the Terror may have exposed him to lead in coal dust which might have found its way into his hair via ingestion and exogenous contamination, but Beattie and Geiger (1987) observed that the lack of callouses 
on his hands indicated that he had been too ill to work for a considerable time prior to death, and further that there is no evidence that the ships' auxiliary engines had been used in 1845. If, as proposed by Farrer (1993), Torrington received different treatment from the surgeons on the Terror than did Hartnell and Braine from those on the Erebus for conditions that may have included tuberculosis, then an iatrogenic factor may have been relevant. The Royal Navy provided 'comforts for the sick' which included wine which was often adulterated with acetate of lead and administered in pewter vessels. Acetate of lead was recognised as a poison but also had medical uses in treatment of diarrhoea associated with tuberculosis and for the common sailors' affliction of gonorrhoea. In this context it is notable that Hartnell's body also contained high levels of mercury (Amy and others 1986) which was a recognised treatment for the equally common affliction of syphilis. The expedition is also known to have suffered widely and severely from chilblains during their time at Greenland (Bell 1881: 126) for which acetate of lead was a recognised treatment as an astringent. The standard Royal Naval 'Medicine Chests Nos. 1 to 4' were stocked according to the size of a ship's complement and all included lead- and mercurybased medications; for example liquoris plumbi acet. and hydrargarum submuriatis (His Majesty's Stationery Office 1835: 56-57). A medicine chest recovered from Victory Point appeared to be non-standard issue for it bore no Government mark and may have been the personal possession of an officer, but it also contained a bottle labelled 'Mur. Hyd.', which would be perchloride of mercury (Cyriax 1947). Only the recovery of the surgeons' sick lists would confirm this speculation about an iatrogenic factor (see final discussion) but it is mentioned here to reinforce the fact that there was the potential for lead to have accumulated from many sources. Re-analysis of the hair might clarify the time-line of accumulation, subject to criticism of the reliability of hair analysis as a marker of exposure (Barbosa and others 2005; Rodrigues and others 2008).

The data from Beechey Island reveal levels of lead in bone, soft tissue and hair that, at the upper range, would be consistent with lead poisoning. Other outcomes of the forensic examinations provide grounds for caution, however. For example, in their examination of the oral cavity, Amy and others (1986) made no mention of 'Burton's line' (a bluish-grey line on the gingiva) which is a common, although not inevitable, sign of lead poisoning (Burton 1840; Pearce 2006; Troesken 2006). Similarly, Notman and others (1987) noted explicitly that there was no calcification of the basal ganglia of the brain associated with lead poisoning, although the portable $\mathrm{X}$-ray equipment used may have lacked the resolution to detect subtle or early changes associated with acute exposure. As the presence of tuberculosis and pneumonia was also suspected (Amy and others 1986; Notman and others 1987), it would be difficult to ascribe the deaths to lead alone.
Given the present focus upon individual variation, the further question is whether there is evidence that other men were subject to the effects of lead at Beechey Island. Beattie and Geiger concluded that 'the effects of lead poisoning [on the three men who died on Beechey Island] were catastrophic' and that others 'would have been as severely affected', but they also allowed that some 'may not have shown any obvious effects of the poison' (Beattie and Geiger 1987: 241-242). If lead poisoning were catastrophic and widespread it is notable that no others died at Beechey Island (unless their remains have yet to be found). Lloyd-Jones (2004: 325) has observed that it is "much more likely [that these men died of tuberculosis] than that they suddenly succumbed to lead poisoning when others did not.' Moreover, if lead poisoning were widespread at Beechey Island one might assume that the consequent reduction in effective manpower would have prevented the expedition from proceeding. In fact, the men were fit enough to construct a well-founded winter base including a site for magnetic observations, several large cairns, one on a 200-metrehigh cliff, and to undertake physically-demanding, manhauled sledging exploration (Cyriax 1939; Hansen 2010; Powell 2006). They also constructed a small garden (an 'anti-scorbutic gardening patch'; Kane 1856: 163) and shooting range which would reflect, respectively, the awareness of the need for fresh greens to ward off scurvy and other dietary deficiencies, and for training in marksmanship which was vital to the procurement of game to supplement their provisions. Such forward planning and physically-demanding activities would seem inconsistent with widespread lead poisoning. The expedition then proceeded when the ice opened later in 1846. In April 1847, Commander Fitzjames of the Erebus could still state 'All Well' (and underline it for emphasis) when signing off the position report deposited at Victory Point. His emphatic statement would not seem consistent with a serious situation affecting the health of a large proportion of the crew some two years into the expedition.

Clearly, however, significant mortality did occur over the following year and it is bone samples from King William Island that offer insight to the state of the crew at the desertion of the ships.

\section{King William Island skeletal remains}

Kowal and others (1989) employed graphite furnace atomic absorption spectrometry to determine the levels of lead $(\mu \mathrm{gPb} / \mathrm{g}$ dry weight) in bones collected from the western and southern coasts of King William Island and which represented an uncertain number of men who had died during the attempt to reach the mainland. Although 23 bones are listed by Kowal and others (1989: Table 1), the correct total is in fact 14 due to an error which had gone undetected until an enquiry by the present authors (Beattie, personal communication, 16 August 2013). These bones comprised a single vertebra, rib and metacarpal, two parietal bones and two ulnae, three femurs and four tibiae (originally published erroneously 
as thirteen tibiae). The mean lead content was 138.1 $\mu \mathrm{gPb} / \mathrm{g}$ (SD 35.0: range 87-223) but the contents of individual bones were not given. Only a very cautious comparison can be made between the mean bone-lead content of this unknown number of men who died after deserting the ships and the three who died two to four years earlier on Beechey Island, but the difference is slight at $10 \mu \mathrm{gPb} / \mathrm{g}$ and the standard deviations of the two samples completely overlap. The very slight difference might imply that there had been little further accumulation of lead during the two- to four-year period leading to, and following, the desertion of the ships, but such a conclusion would be very tenuous given the small numbers involved. Similarly, whilst the wide range of lead content of the King William Island bones might imply considerable inter-individual variation in accumulation of lead, it cannot be confirmed because it is quite uncertain whether several bones may have belonged to the same man.

Clearer insight to inter-individual variation in lead burdens is found in a highly detailed study by Keenleyside and others (1996) of a further sample of 52 bones collected from a site at Erebus Bay on King William Island which was relatively near to the point where the ships were deserted. A non-destructive X-ray procedure was used to estimate bone-lead content. Depending upon the bone type, the ranges observed were either wider or narrower than the overall range of $83-223 \mu \mathrm{gPb} / \mathrm{g}$ observed by Kowal and others (1989 above); for example, the ranges for the tibia $(62-151 \mu \mathrm{gPb} / \mathrm{g})$ and femur (103-203 $\mu \mathrm{gPb} / \mathrm{g}$ ) were narrower, while those of the radius (73-373 $\mu \mathrm{gPb} / \mathrm{g}$ ) and (most extremely) the vertebra (580-1740 $\mu \mathrm{gPb} / \mathrm{g}$ ) were wider. The overall greater range may simply reflect the larger sample size of Keenleyside and others which would inevitably tend to sample a wider range of the crew's lead levels. (Parenthetically, if the exceptionally high levels seen in the vertebrae are reliable, they might seem difficult to reconcile with the levels that could possibly have been accumulated from the canned provisions, particularly in light of comments by Farrer 1993). The different procedures used by Kowal and others (1989) and Keenleyside and others (1996) to determine bone lead may also account for some of the differences between the studies. When, in a later study, Keenleyside and others (1997) employed the same procedure as Kowal and others (1989) in a re-analysis of a sub-set of the data of Keenleyside and others (1996), the levels of lead in two of the tibiae differed by $+34 \%$ and $-18 \%$ respectively from the levels reported in the earlier publication. This fact is not obvious from the two publications themselves but was confirmed by Keenleyside (personal communication, 19 July 2013) following enquiries from the present authors. Thus, the potential for substantial measurement variation must be borne in mind in addition to any 'real' inter-individual variation in bone lead. Hie and others (2008) have discussed in detail the variable consistency of data derived from in vivo assessment of bone lead.
As the lead contents of different bones within an individual have been shown to bear particular relationships (Wittmers and others 1988), Keenleyside and others (1996) employed established techniques to allocate sets of bones to seven separate skeletal identities. Data adapted from Tables 2 and 3 of Keenleyside and others (1996) are presented in Fig. 1 for the seven skeletons identified by the latter authors. The range of lead values was very wide but, as there was no reason to suppose that extreme values were anomalous, they were not excluded as outliers. Missing data points were not interpolated.

\section{Whole-crew (population) estimates of lead burdens}

An analytic procedure was applied to the data in Fig. 1 to allow estimation of the variation in 'population' lead levels across the crew (after Galwey 2006). Analysis employed the 'nlme package' in the R Statistical Computing Environment (Pinheiro and Others 2013) The data in Fig. 1 were modelled first with a factor which reflected the different mean lead concentrations in each bone. More critically, a 'random factor' was included to capture the variation in lead levels from individual to individual. Specifically, the underlying lead level associated with each person is assumed to be drawn from a normal distribution with mean $=0$ and standard deviation (SD) $=\delta_{\mathrm{s}}$ and so this distribution reflects the variation in lead levels among the crew.

It was evident from initial data analysis and visual inspection of Fig. 1 that the range was very wide, that the distribution had a positive skew and that the SDs of the lead values for each bone increased as a function of their respective means. A logarithmic transformation was therefore applied as a very effective way of placing the data on a scale of variation which was constant across bones and served to provide a closer approximation to a Gaussian distribution which is a requirement of the analytic procedure. The abscissa of Fig. 1 has been constructed on a log scale which still allows lead levels to be referenced on the original measurement scale of $\mu \mathrm{gPb} / \mathrm{g}$.

An important caveat applies to this analysis. The sample is small and the identities of the skeletons are unknown so that it is uncertain whether they are a representative sample of the 105 crewmen. Nothing is known of variables that might influence the lead burden such as age (and thus life-time exposure to lead), education and rank, and previous occupational exposure to lead: such variables would normally be covariates in an analysis.

The random effects model estimates the SD of mean lead levels across the crew members on the log scale as 0.48 (95\% CI $=0.27-0.85)$. The shaded area in Fig. 1 allows the meaning of this variation to be expressed on the original measurement scale of $\mu \mathrm{gPb} / \mathrm{g}$ by calculating (mean $+/-2 \mathrm{SDs}$ ) on the log scale and transforming the end points of these intervals back to the original scale. The variation shown in Fig. 1 then allows estimates to be made of the proportion of the crew whose bone 


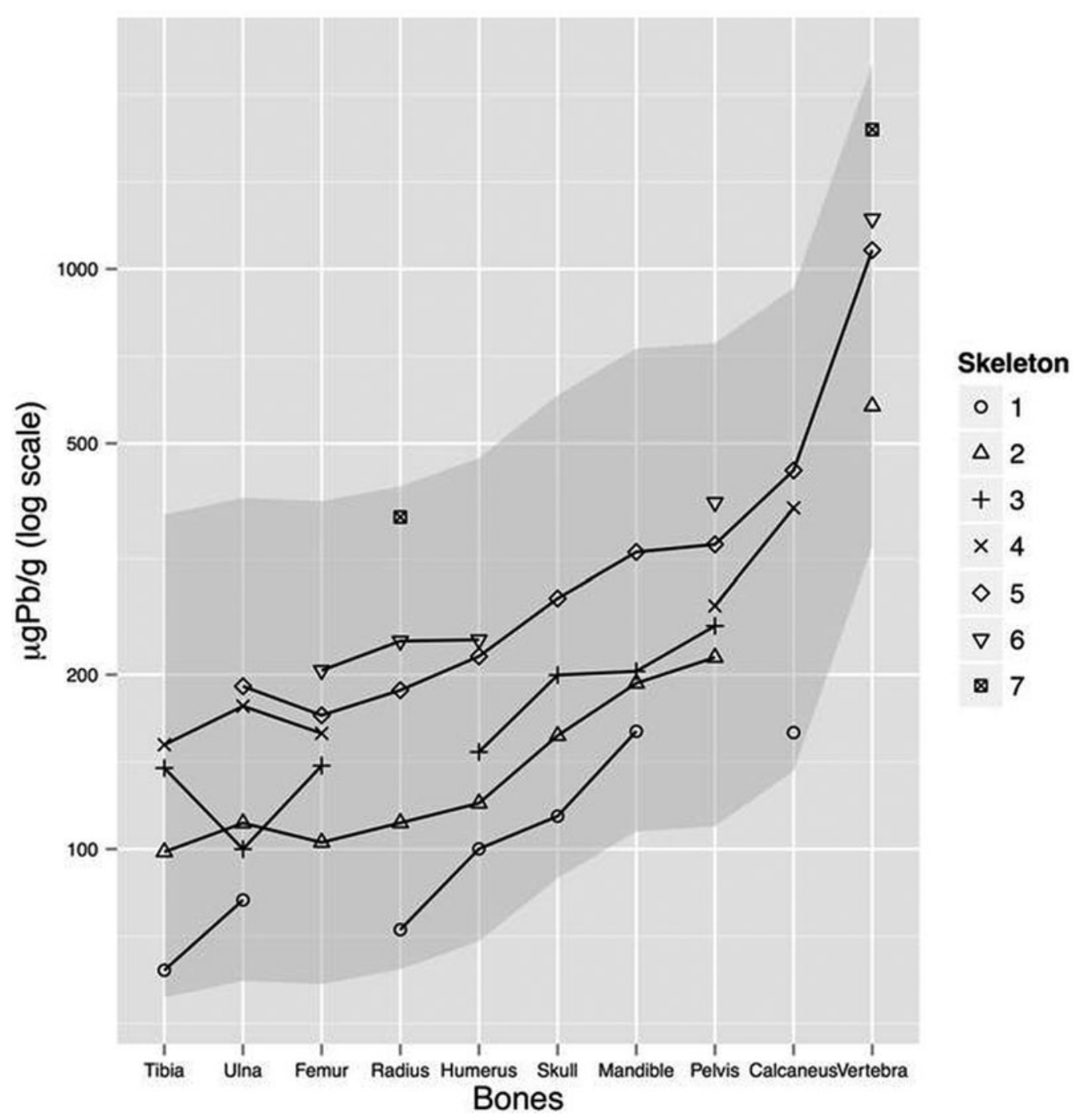

Fig. 1. An estimation of the distribution of lead $(\mu \mathrm{gPb} / \mathrm{g})$ across the Franklin crew as calculated from the bones of seven individual skeletons (individual raw data from Keenleyside and others 1996: adapted with permission). The shaded area encompasses $+/-2$ standard deviations around the mean bone-lead and therefore represents approximately $81 \%$ of the crew.

lead levels fell above or below any nominated value of interest.

The overall implication of the shaded area of Fig. 1 is that levels of bone lead differed very substantially across the crew. The proportions of men who carried particular lead burdens can be estimated very cautiously. Formally, one SD encompasses $68.2 \%$ of values around the mean and thus corresponds to $\sim 72$ of the 105 crew, half of whom $(\sim 36)$ would have lead levels above, and half below, the mean. Two SDs account for a further $13.6 \%$, or 28 men of whom 14 would have values below, and 14 above, the mean. The remaining $\sim 5$ men would lie in the tails of the distributions between 2 and 3 SDs above or below the mean. It is then deducible that, overall, some $14(13 \%)$ to $16(15 \%)$ men would have bone-lead levels between -1 and -3 SDs below the mean and would have carried relatively lower burdens of lead. A corresponding number between +1 to +3 SDs would, obviously, have had relatively higher levels.

\section{Implications for Franklin's crew of present-day studies of lead-related neurocognitive and physical morbidity}

The crew's tibia lead data are of particular relevance because they allow cautious comparison with presentday studies of the relationship between cognition and tibia lead which have been made by in vivo estimation of tibia lead using X-ray methodology similar to that of Keenleyside and others (1996). The tibia is composed principally of cortical bone which provides a stable storage of lead with a long half-life recently estimated as 48.6 years (Wilker and others 2011) and thus is a reliable indicator of cumulative exposure. The crew's tibia data (from Keenleyside and others 1996) are shown in Fig. 2 which also shows tibia lead from five studies of the association between lead and cognitive function in present-day samples (Bleeker and others 1997, data from Table 1 for age group 24-43 years; Hänninen and others 1998, data from Table 1 for subjects with $\mathrm{BPb}$ 


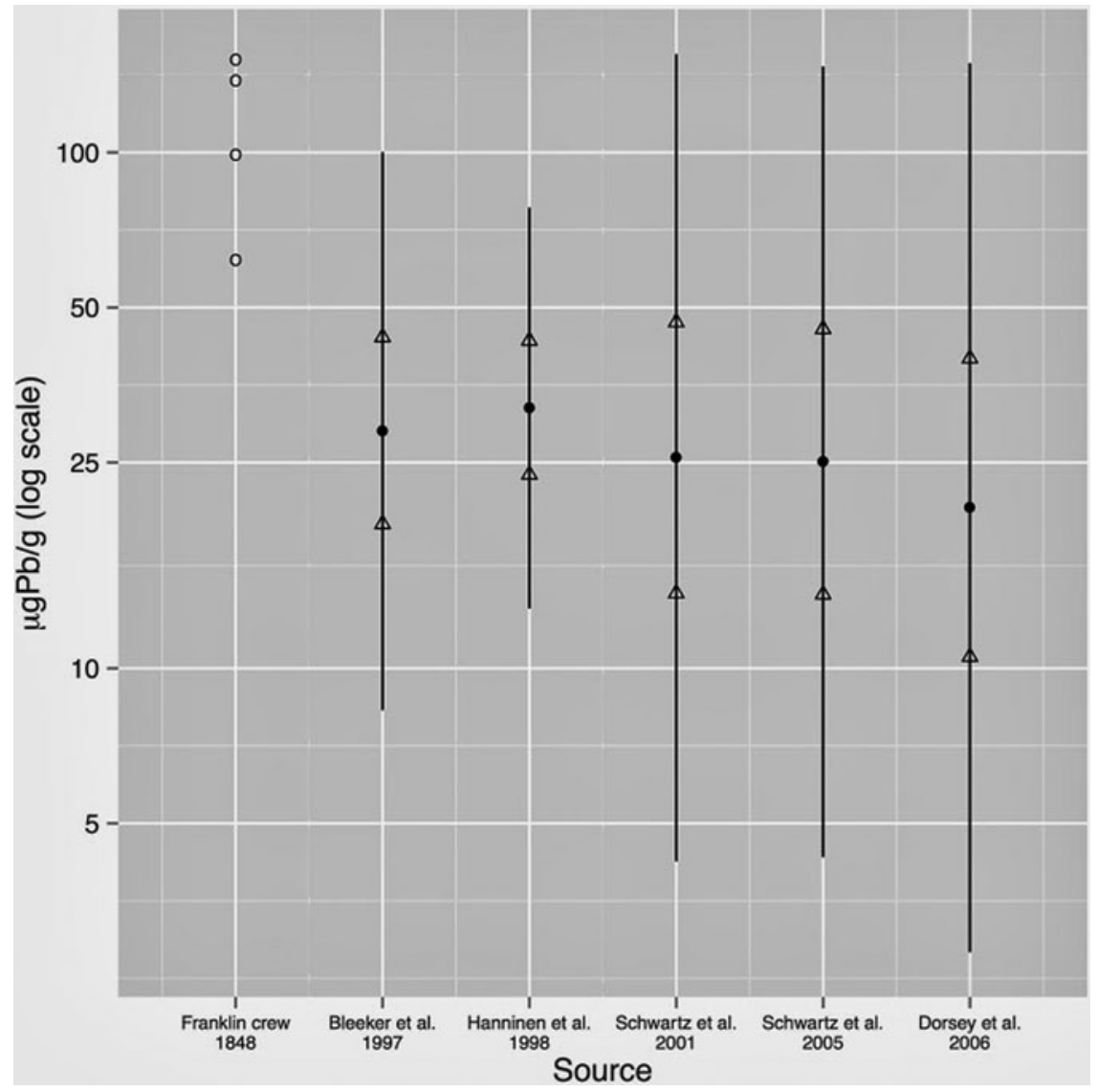

Fig. 2. Tibia lead $(\mu \mathrm{gPb} / \mathrm{g})$ of four Franklin crew (Keenleyside and others 1996) compared to five present-day studies (means and 2 standard deviations: $\Delta=$ inter-quartile range). Bleeker and others (1997); Dorsey and others (2006); Schwartz and others (2005): reproduced with permission of Wolters Kluwer Health / Lippincott, Williams \& Wilkins, and American Academy of Neurology (Bleeker and others 1997). Hänninen and others (1997): reproduced with permission of BMJ Publishing Group Ltd. Schwartz and others (2001): reproduced with permission of Oxford University Press.

max >2.4; Schwartz and others 2001, data from Table 3; Schwartz and others 2005,109; Dorsey and others 2006, data from Table 2). The studies are relevant because their participants may approximate, although imperfectly, to the Franklin crew at the time of deserting the ships: their age distribution only slightly exceeds the crew's range of 21-52 (the range excludes Franklin himself who died before the desertion of the ships); the subjects have current occupational lead exposure and therefore bear comparison with the contaminated nineteenth-century population; the subjects are living in the community and apparently functioning normally.

The very small sample of crew tibiae available for analysis is clearly a severely limiting factor and it would be inappropriate to attempt to construct a distribution from four data points in order to allow comparison with present-day studies. The authors sought to increase the sample size by including the four tibiae in the sample of Kowal and others (1989) but, regrettably, the data could not be obtained. Their inclusion might, in any case, have introduced further uncertainty if it could not be determined whether the tibiae were from different individuals.
Given these considerations, the tentative nature of the following discussion must be emphasised.

The levels of lead in the four individual tibiae from Keenleyside and others (1996) are plotted in Fig. 2. It may reasonably be proposed that the tibiae of the remainder of the crew would be distributed around those four values with a positive skew as evident in Fig. 1, but where the end points of the range cannot be determined. In order to be consistent with the log scale employed in Fig. 1, the data for the present-day studies shown in Fig. 2 have been transformed from their original scales to a log scale. This transformation would seem appropriate because the prediction intervals on their original scales led to lower end points below 0 , which is a clear indication that a normal model on several of these original scales is not appropriate. Schwartz and others (2001: 455) have described how the procedure for estimating tibia lead can result in some values of less than zero. As the mean $(\mu)$ and $\mathrm{SD}(\delta)$ on the log scale relate to the mean and variance on the original scale through the following formulae where 'exp' denotes the exponential function, the means and variances of the present-day studies were 
transformed by simple inversions of these formulae

$$
\begin{gathered}
\text { Mean }: \exp \left(\mu+\delta^{2} / 2\right) \\
\text { Variance }:\left(\exp \left(\delta^{2}\right)-1\right) \exp \left(2 \mu+\delta^{2}\right)
\end{gathered}
$$

The resultant means, confidence intervals and interquartile ranges are shown in Fig. 2.

It is evident that the crew's data points lie outside the upper quartiles of the present-day distributions, but they are encompassed by the confidence intervals of Schwartz and others $(2001,2005)$ and Dorsey and others (2006), and partially so by those of Bleeker and others (1997) and Hänninen and others (1998). It may be tentatively proposed that the association between high levels of tibia lead and cognitive function in the present-day studies may be broadly reflective of effects in crewmen having those same levels of lead. The study by Bleeker and others shows an overlap with the notional lower distribution of the crew: they found no relationship between tibia lead on cognitive performance in a sub-group of exposed workers who were broadly equivalent in age to the majority of the crew ( $<43$ years of age). The study by Hänninen and others shows a similar overlap with the lower distribution of the crew and found no association between tibia lead and performance. There was, however, an association between blood lead and performance on tests of attention, verbal comprehension and visual and motor co-ordination. As there are no crew data for blood lead, this result will be considered later below. Thus, within the range of overlap of the two studies with that of the lower tibia lead levels of the crew, there is little evidence of associated cognitive impairment.

Fig. 2 shows the studies by Schwartz and others (2001, 2005) and Dorsey and others (2006) which involved longitudinal follow-up of a large cohort of leadexposed workers. Early in the follow-up period, Schwartz and others (2001) found no relationship between tibia lead and cognition, but a reliable association between blood lead and tests of speeded co-ordination and attention (discussed later). In later follow-up, significant associations were found between both tibia and blood lead and decrements in higher-order executive functions involving planning, decision-making, memory and manual dexterity (Schwartz and others 2005).

In the case of Dorsey and others (2006), increasing levels of both tibia and blood lead were associated with slower reaction time and impaired executive function. It may be of particular relevance to the crew that the greatest adverse effect of lead was upon the task of 'pursuit aiming'. Given that in the later stages of the expedition, and certainly after deserting the ships, the crew would have depended upon procuring fresh meat by hunting, any impairment of the ability to aim a weapon accurately would have had serious consequences.

The evidence that poorer cognitive test scores in present-day samples were associated with levels of tibia lead which overlapped with the lower distribution of that of the crew might imply that broadly similar effects would have been present in the crew. If so, then given that the subjects in the present-day cohorts were all employed and functioning normally in the community, it would appear that the degree of impairment due to lead, while statistically significant, is not of a nature or extent to impair everyday function. The matter of test sensitivity is relevant here. The studies cited above used sensitive neuropsychological assessments of the relationship between lead and cognitive function. They confirmed a significant inverse relationship that is consistent with the known effects of lead upon mid-brain structures and the occipital and frontal lobes (Hsieh and others 2009; Sanders and others 2009; Stewart and others 2006). However, the sensitivity of such assessments means that whilst the effects are statistically significant, they may be subtle and not readily evident in everyday functioning. In this respect it is evident from the data tables of the studies cited above that the $\beta$ coefficients describing the significant effects of lead upon cognition are often relatively small.

It is also relevant that whilst present-day studies confirm an overall significant relationship between lead and cognitive function, there is known to be marked individual variation in susceptibility to the effects of the metal. For example, great variability is clearly evident in the scatterplots relating tibia and blood lead to cognitive performance in the data of Schwartz and others (2001: Figs. 1 and 2) and for tibia in the data of Stewart and others (1999: Figs. a to k). Similar variability is evident in the results of Weisskopf and others (2004: Figs. 1 and 2) in an older group of lead-exposed workers. Earlier research has also shown an obvious overlap in cognitive performance between lead-exposed and nonexposed workers (Baker and others 1984) and that even when performance is 'significantly' impaired relative to a non-exposed group it may remain within the normal range of function (Grandjean and others 1978). On this evidence, the proportion of the crew with levels of tibia lead within the upper range of the present-day samples shown in Fig. 2 may have experienced effects of lead on their cognitive function that would not be incapacitating.

The considerations above would lead to the conclusion that members of the crew whose tibia lead exceeds that of the present-day samples would have suffered proportionally greater impairment. Whether such impairment would have been associated with frank incapacity must be considered in light of the variability already noted in the studies above and the very high individual levels of tibia lead also reported by Schwartz and others and Dorsey and others in their apparently normallyfunctioning subjects. For example, the range of tibia lead reported by Schwartz and others (2005: 109) extended to $338 \mu \mathrm{gPb} / \mathrm{g}$ which would encompass a large proportion of the crew's estimated tibia lead shown by the shaded area in Fig. 1. Equally, however, when considered in population terms, the cognitive function of a proportion of individuals is likely to be affected at such levels and 
it would be reasonable to conclude that some of the crew would have experienced a decline in function.

\section{Blood lead and neurocognitive and physical morbidity}

Tibia lead reflects the individual's long-term exposure to, and accumulation of, the metal. However, the level of lead currently circulating in the blood, and thus having the potential to exert immediate effects upon the brain and other organs, may be a more relevant metric (Shih and others 2007). It was noted above that several of the present-day studies found associations between blood lead and cognition in the absence of tibia-lead associations. The difficulty with respect to the Franklin expedition is that there are no blood-lead data for the crew, but Keenleyside and others (1996) estimated blood lead from the tibia data shown in the present Fig. 2. Their estimate was based on evidence that a blood-lead concentration of $20 \mu \mathrm{gPb} / \mathrm{dl}$ would increase tibia lead by $1 \mu \mathrm{g}$ if maintained for 1 year (after Cake 1994 unpublished). Whilst Hu and others (2007) have largely confirmed the latter relationship, there is evidence of nonlinearity in the association between tibia lead and blood lead so that prediction of the latter must be considered cautiously (Healy and others 2008; Schwartz and others 2008). Keenleyside and others (1996) postulated what might be termed a 'worst-case' assumption that one half of the lead in the four tibiae (range $60-150 \mu \mathrm{gPb} / \mathrm{g}$ ) had been accumulated during the three years of the expedition (thus approximating to one half of the range, i.e. $30-75 \mu \mathrm{gPb} / \mathrm{g}$ ). On the basis of this assumption, the blood-lead equivalent was then calculated to be 600 $1500 \mu \mathrm{gPb} / \mathrm{dl}$, which would correspond to blood lead during the expedition of $200-500 \mu \mathrm{gPb} / \mathrm{dl} /$ year which, as Keenleyside and others concluded, would represent significant lead poisoning.

However, the assumption that one half of the crew's lead burden was accumulated over three years would require a source of considerable lead contamination over and above the background level present as part of nineteenth-century life aboard ship. This has prompted a speculative search for a possible source which would be sufficiently potent. One such could have been the ships' 'soft' drinking water which would dissolve lead from storage tanks and pipes (Battersby 2008; Battersby and Carney 2011; Farrer 1993). However, the assumption that half of the total lead burden was incurred during the three-year expedition has the problematic corollary that the other half must have been accumulated over a preceding median lifetime of 29 years (the median age of the crew at the time of embarking on the expedition). If so, then, following the calculation procedure of $\mathrm{Hu}$ and others (2007: 458), the accumulation would correspond to an annual blood-lead range of only $21-52 \mu \mathrm{g} / \mathrm{dl}$, the lower range of which falls well below current recommended exposure limits in the United Kingdom (>50 $\mu \mathrm{g} / \mathrm{dl}$ requires remedial action; $>60 \mu \mathrm{g} / \mathrm{dl}$ requires suspension of a worker from duties: Health and Safety Executive
2012). The range would seem implausibly low in light of the known lead contamination of nineteenth-century Britain.

Given this difficulty, a parsimonious assumption would be that lead accumulated at largely the same rate prior to, and during, the expedition. It would seem plausible that the well-recognised sources of lead contamination on land and during employment on previous voyages (that is ingestion via food, tableware and drinking vessels, water supplies, atmospheric dust etc.) would be largely replicated during the expedition. When re-calculated on this basis, the estimate of blood-lead range at the time of deserting the ships is 38-94 $\mu \mathrm{gPb} / \mathrm{dl}$ (median years of accumulation being 32 years by that time). The latter range certainly exceeds current United Kingdom exposure recommendations and would be consistent, at higher levels, with the degree of blood-lead-related reduction in cognitive function observed in present-day studies (Hänninen and others 1998; Schwartz and others 2005; Dorsey and others 2006).

A tentative insight to the possible distribution of blood lead in the crew, and its associated physical effects, is provided in Fig. 3. The blood-lead equivalents (median 32-year lifetime) of the four tibiae lead levels available to this analysis (from Keenleyside and others 1996, as described above) were calculated after $\mathrm{Hu}$ and others (2007) and are shown as single points along the $\mathrm{X}$ axis in Fig. 3. The figure also shows the gradual increase in type and severity of symptoms as blood lead increases from 10 to $80 \mu \mathrm{gPb} / \mathrm{dl}$ and beyond (adapted from Kosnett and others 2007: Table 1). Given that there are only four data points, and that these are themselves estimates rather than objectively-determined levels of blood lead, it was thought highly inappropriate to construct yet another estimate of the distribution of blood lead across the crew. Rather, following the example of Fig. 2 above, on the basis of visual inspection of Fig. 3 it may reasonably be proposed that the blood levels of the crew would be distributed around those four points but that the minimum and maximum values of the range cannot be determined.

Fig. 3 shows that symptoms of lead intoxication become more likely as blood lead levels rise above approximately $40 \mu \mathrm{gPb} / \mathrm{dl}$, but one should note that the latter level is not a threshold at which symptoms must immediately appear. High levels of blood lead are not inevitably associated with the symptoms shown in Fig. 3 and it has been noted that clinical symptoms may rarely be seen below $60 \mu \mathrm{g} / \mathrm{dl}$ (Needleman 2004). It may tentatively be proposed that a proportion of the crew whose blood lead was below $60 \mu \mathrm{gPb} / \mathrm{dl}$ would have experienced few subjective ill-effects or mild to moderate symptoms including those classically associated with chronic lead exposure such as hypertension, mild headache and gastric disturbance. A proportion of these men would have had blood-lead levels at the thresholds of the United Kingdom Health and Safety Executive's (2012) current recommendations for investigative action or suspension of a worker. Equally, those whose blood 


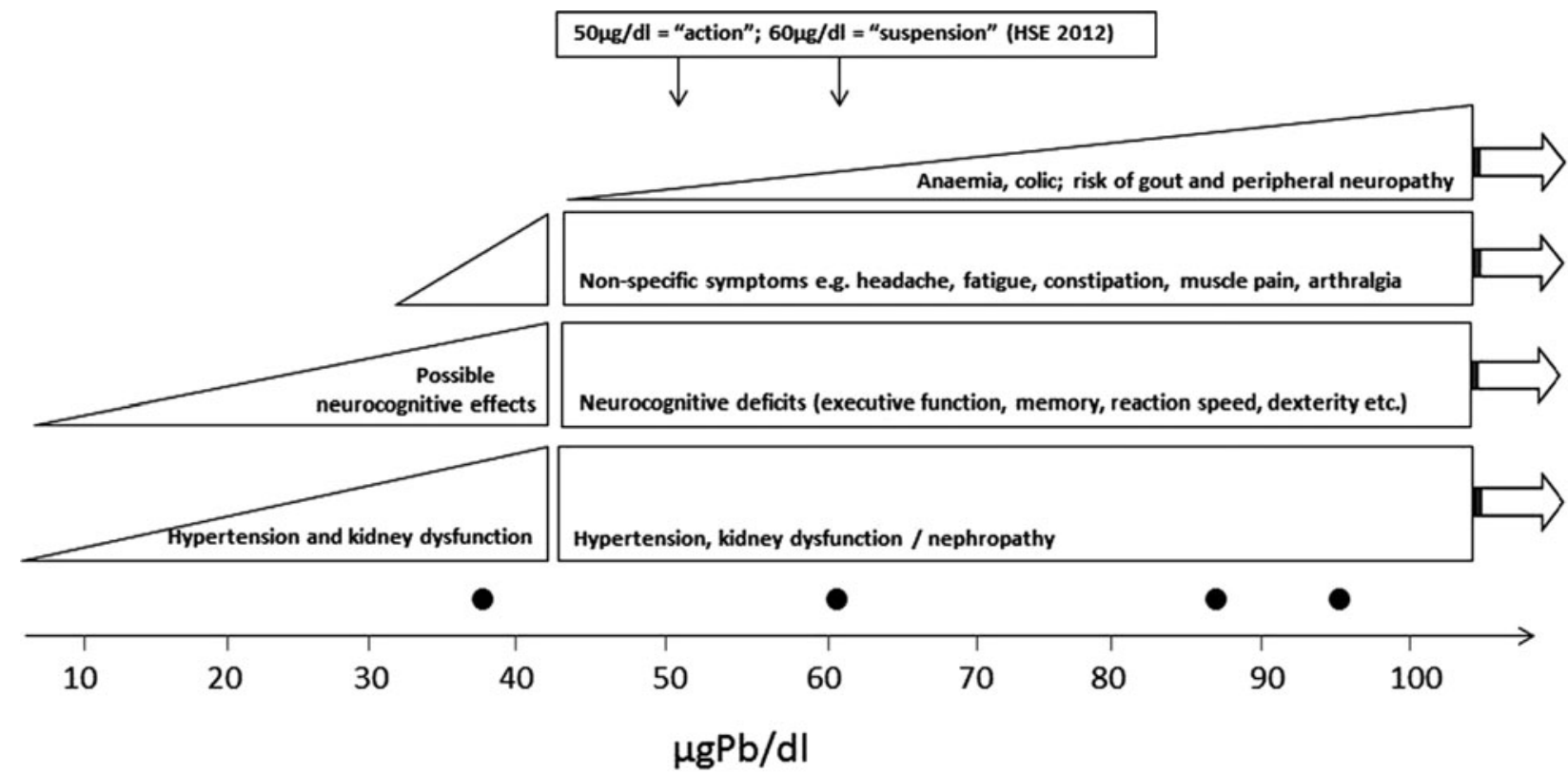

Fig. 3. Symptoms associated with increasing levels of blood lead ( $\mu \mathrm{gPb} / \mathrm{dl})$ adapted with permission from Kosnett and others in Environmental Health Perspectives 2007; 115 (3): 463-471. • = blood-lead levels calculated from the four tibiae of the Franklin crew. The United Kingdom's Health and Safety Executive's (2012) recommended blood-lead thresholds for 'action' and 'suspension' of a worker are also shown for contemporary comparison.

lead exceeded some $80 \mu \mathrm{gPb} / \mathrm{g}$ would be at increasing risk of more serious morbidity including neuropathies, severe colic and anaemia (Gordon and others 2002).

The very limited data available make it is impossible to draw conclusions from Fig. 3 as to the proportions of men who might have suffered particular symptoms. Conclusions would, in any case, be uncertain in view of the long-standing clinical observation that a degree of tolerance develops to chronic lead exposure and that there is 'substantial inter-individual variability in susceptibility to symptomatic adverse effects' (Kosnett and others 2007: 464). A final difficulty concerns the fact that the estimation of blood lead uses the duration of exposure (that is age) as a denominator in the calculation. Here, the median crew age of 32 years at desertion of the ships has been used because there is no information as to the age of the men whose tibiae are involved. However, it is readily seen that the blood-lead equivalent calculated for any given tibia would be substantially lower if the man were one of the oldest of the crew, and substantially higher if he were one of the youngest. Such unknown factors conspire with the limited data available to render conclusions highly tentative.

\section{Factors moderating the effects of lead}

Final consideration can be given to four factors that might have contributed to individual variation in debility by exacerbating or mitigating the effects of lead.

\section{Nutritional deficiencies}

The fact that many of the crew appeared to have died within a short distance of deserting the ships has been taken as evidence for marked debility at that time. Similar debility was recorded on other Arctic missions, particularly when more than two winters had been endured. Nutritional deficiencies were often to blame and vitamin $\mathrm{C}$ deficiency commonly led to scurvy (for example Armstrong 1853; Robertson 1849). The state of provisions at the time of deserting the Erebus and Terror is unknown. The expedition was supplied with lemon juice as an antiscorbutic agent but Cyriax (1939) proposed that storage conditions and time reduced its effectiveness and caused widespread scurvy, although this has been cast in doubt by Mays and others (2013) on the basis of their evaluation of skeletal evidence. A daily minimum of $10 \mathrm{mg}$ of vitamin $\mathrm{C}$ will preclude scorbutic symptoms in men engaged in light work (Pemberton 2006) and may have been sufficient when idle whilst beset, but men sent on sledging expeditions would have required more. Vitamin $\mathrm{C}$ is relevant to lead exposure because serum levels of ascorbic acid are inversely related to blood lead, probably due to altered intestinal absorption and renal clearance (Cheng and others 1998; Dawson and others 1999; Simon and Hudes 1999).

Vitamin D is associated with increased levels of blood lead in winter. The mechanism is complex (see Cheng and others 1998; Onalaja and Claudio 2000; Sanders and others 2009) but a factor of relevance to the expedition is that of exposure to sunlight in the body's synthesis of vitamin D. Oliveira and others (2002) propose that reduced sunlight in winter leads to lower levels of vitamin $\mathrm{D}$ which, in turn, result in increased resorption of lead from bone into the blood. The crew's 'last' winter of 1847-1848 involved more than two months of darkness so that an increase in blood lead in men with existing high levels may have exacerbated other physical morbidity and 
contributed to a debilitated state when the ships were deserted in April 1848.

\section{Stress}

The effect of lead on cognition is exacerbated by stress, putatively because both activate the hypothalamicpituitary axis to release cortisol which is associated with impaired cognitive function (Peters and others 2010; Virgiolini and others 2005). Increasing stress during the final months preparing to desert the ships may have contributed to debility in those with a higher lead burden.

\section{Genetic factors}

The adverse neurocognitive effects of lead are greater in individuals who carry the $\varepsilon 4$ allele of the apolipoprotein $\mathrm{E}$ gene which is implicated in elevated deposition of $\beta$-amyloid in the brain (Stewart and others 2002). We have confirmed modest effects of the allele which are less evident in younger age (Millar and others 2003). Given a median crew age of 32 years at desertion of the ships, and that some $30 \%$ of the population carry the $\varepsilon 4$ allele, the number potentially affected would be small. Complex genetic influences upon variables affecting the accumulation of lead have also been proposed via effects including carrier proteins for lead in the blood, and vitamin D synthesis, but are beyond discussion here (see Scinicariello and others 2010). Whilst there has been much attention devoted to factors influencing the accumulation of lead, The Editor of this journal has also observed that individual variation in excretion of lead may be highly relevant. Support for this proposal is found in the observation by Barbosa and others (2005) that individual variation in the burden of body lead may be wrongly attributed to exogenous sources when, in fact, it reflects inter-individual variation in physiological processes involved in urinary and faecal excretion of the metal.

\section{Cognitive reserve}

One factor may have been protective. Individuals vary in their degree of 'cognitive reserve' (Reed and others 2010) which buffers the brain against the harmful effects of physical injury and some neurotoxins, and is positively associated, in part, with longer education, higher occupational status and intellect. Cognitive reserve protects against effects of chronic lead exposure on higher mental functions (Bleecker and others 2007) and may therefore have afforded some men a degree of protection from the cognitive effects of lead and other debilitating conditions. If some of those men were officers then there might have been positive implications for planning and morale, at least in the short term.

\section{General conclusions}

Considerable caution is required in drawing conclusions from the present analysis. The levels of lead, whilst high relative to those of today, are estimated to have varied widely across the crew. It is not clear that these levels, and their variability, would have been unusual in nineteenthcentury Britain. The overlap of the distributions of lead burdens between present-day, lead-exposed subjects and the Franklin crew implies that at least a proportion of the men, those with lower burdens, would have been little, if at all, impaired. If the estimated range in lead burden across the crew was similar to that of the 'on-shore' nineteenth-century population where lead poisoning was not uncommon (Hernberg 2000), then it would be logical to assume that some of the crew with high burdens may have been at risk of experiencing significant symptoms. Whether the nature and degree of those symptoms would have led to wide-scale incapacity must be considered in light of evidence that some present-day individuals may have high levels of bone and blood lead that do not appear to prevent their remaining in employment and apparently functioning 'normally'. This conclusion is consistent with the long-known development of tolerance to chronic lead exposure and inter-individual variability in susceptibility to its adverse effects (Kosnett and others 2007; Moore 1986; Moore and others 1982; Watson 1857). Equally, whilst the adverse effects of lead may not have been incapacitating alone, they may have contributed to significant debility by interacting with factors such as dietary insufficiency, stress and despair.

The present results may contribute to the debate as to the failure of the expedition. The long-supposed central role of scurvy (Cyriax 1939) has been questioned by the outcome of recent skeletal analyses by Mays and others (2013). Their conclusions would be consistent with evidence of considerable variation amongst Royal Navy crewmen in susceptibility to scurvy despite having ostensibly similar diets, and even when subject to great privation (see sick lists of Anderson 1855; Armstrong 1853; Bradford 1851; Lyall 1854; Robertson 1849; Sutherland 1852). The present analysis also indicates considerable variation in bone-lead content across the crew which may imply that any effect of lead may have differed widely between individuals. In turn, this may imply that the popular attribution of the disaster to lead poisoning may merit reconsideration. In a similar way, the supposed over-reliance of the expedition on canned provisions (whether lead-tainted or not) has been used to underpin ethological interpretations for its failure. For example, Attwood (1995) and Stefannsson (1939) have proposed that the expedition's reliance on modern canned provisions and reluctance to resort to 'primitive' Inuit methods of hunting and fishing, left the expedition fatally exposed when those provisions ran short. However, Cavell (2009) has observed that there is no evidence that the expedition failed to adopt such methods, or that British commentators of the time attached any stigma to adopting Inuit methods if the need dictated. It is relevant that Lieutenant Irving of the Terror stated in his last letter that the expedition intended to 'eke out our provisions with all the game our guns can procure' (Bell 1881: 126). It was the expedition's great misfortune that it became 
beset in an area of the Arctic where game was least likely to be procured (Cavell 2009).

Other uncontroversial factors that are well known to have afflicted polar exploration may have played a significant part in the disaster and include exposure, infections and starvation, and all may have interacted with any adverse effects of lead. Lambert has proposed that tuberculosis may have underlain the expedition's high overall mortality rate (Lambert 2009: 348), the disease being common in nineteenth-century naval crews. Moreover, individual causes of death may have varied widely. For example, Mays and others (2011) have shown from the examination of skeletal remains that the death of one officer may have been due to severe dental infection. A single fatal accident involving a group composed principally of officers would explain the disproportionate death rate seen amongst the officers when compared to the other men. Such variation in the causes of mortality and morbidity is well illustrated in the surgeons' sick lists of the squadrons sent in search of the expedition, and notably in the case of HMS Investigator whose crew very nearly met the same fate as Franklin's men (Armstrong 1853). Most telling, perhaps, is the evidence from ice core analysis that the expedition's attempted passage through the Arctic coincided with climatic conditions where there was a maximum of only one year in five when open water was present in the critical areas of Peel Sound and Franklin and Victoria Straits (Alt and others 1985). Once beset, the expedition had little chance of release. The present conclusion would therefore be to concur with authors who have observed that the expedition was overwhelmed by a combination of factors, some of which may have been health-related, but also included hostile climate and terrain, inadequate cold-weather clothing and equipment and, ironically, its success in reaching a location so remote as to defeat rescue or escape (Lambert 2009, Williams 2010; Woodman 1991).

There are a number of significant limitations to the present analysis. First, the available sample sizes are small so that only cautious estimation can be made of effects in the whole crew. Secondly, Keenleyside (personal communication, 19 July 2013 has noted that measured levels of lead from the same bone will vary depending upon the analytic procedure and bone site sampled: clearly such variation will affect the replication of effects and raise uncertainty as to the absolute lead burden of the crew. Thirdly, comparisons between Franklin's men and lead-exposed, present-day groups must be tentative and illustrative, rather than definitive, as to the effects of lead on the crew. The central difficulty is that conclusions are greatly hampered by the lack of control data which would allow reliable determination of whether the levels of lead found in Franklin's men were typical of contemporary Royal Navy crews who had been on similar missions, and of the nineteenth-century population as a whole. There would be considerable practical impediments to obtaining such control data but it would offer the means to a definitive test of the lead-poisoning hypothesis.
Finally, the loss of practically all of the expedition's records greatly limits an understanding of factors that contributed to the disaster. Royal Naval surgeons were required to keep sick lists describing morbidity and mortality amongst the crew. The lists kept by surgeons with the ships searching for Franklin show great attention to signs and symptoms (for example Anderson 1855; Armstrong 1853, 1857; Bradford 1851; Lyall 1854; Robertson 1849; Sutherland 1852), and it is certain that the expedition's senior surgeons, Stephen Stanley and John Peddie, would have kept similar lists. The symptoms of lead poisoning were well described in medical texts and pharmacopeia at the time when the expedition's surgeons were in training or practice (Elliotson 1839; Hooper 1839; Thomson 1822; Turnbull 1806). Indeed, Thomson described mass lead poisoning on a British merchant vessel (Thomson 1822: 447) and Turnbull provided extensive detail of symptoms in his textbook for naval surgeons (Turnbull 1806: 179-182). If frank symptoms of lead poisoning had been present, it is plausible that Stanley and Peddie would have recognised them and attempted to identify the source and prevent further exposure. Such action would not have been unprecedented: a contemporary Royal Navy surgeon identified mercury poisoning in his crew and implemented procedures to mitigate the effects (Burnett 1823; Doherty 2004). It would greatly inform present-day speculation to know whether the surgeons recorded signs and symptoms of lead poisoning and what actions they took, but only the recovery of their sick lists would answer such questions. Whilst Cyriax (1969) concluded that it is unlikely that any further records will be found, it is notable that a record deposited by the ill-fated search for Franklin of 1852-1854 led by Sir Edward Belcher was recovered in 1976 (Phillips 1985).

The final weeks of the expedition were undoubtedly a time of great suffering as an unknown number of the survivors resorted to cannibalism to stave off starvation to remain alive (Keenleyside and others 1997). Markham (1921: 247) was reluctant to consider this phase of the expedition, writing that 'A veil should be drawn over the last struggles of brave men fighting cold, disease and hunger.' McClintock acknowledged in private correspondence that cannibalism had probably occurred (Cavell 2013), but omitted that detail in his published account in deference to the sensitivities of the relatives and to better-serve the men's memories by more general acknowledgement of their plight (McClintock 1859). Lloyd-Jones (2004, 2005,2011 ) has also well served their memories by researching in detail the backgrounds of many of 'the men who sailed with Franklin' and, in so doing, has elevated them as distinct individuals from a mere scattering of bones on King William Island. Perhaps the evidence presented here of variation in levels of lead amongst the crew, and in susceptibility to the effects of lead poisoning and other adverse factors, may contribute to LloydJones' representation of Franklin's men as individuals, a proportion of whom may have met their inevitable end 
with more fortitude and dignity than some portrayals of the expedition's final days have allowed.

\section{Acknowledgements}

The authors are most grateful to Dr Simon Mays and Dr Janice Cavell for expert and constructive criticism of an earlier draft of the present study. Dr Cavell also kindly provided access to material 'in press'. They are also most grateful to Dr Anne Keenleyside and Professor Owen Beattie who provided further information and guidance as to the published data concerning the levels of lead in the remains of the crew, and to the Editor who drew the authors' attention to the potential role of individual variation in excretion of lead as a relevant but neglected factor. The authors are also grateful to Elsevier Publishers for permission to adapt the data in Tables 2 and 3 of Keenleyside and others (1996) for the present Figs. 1 and 2, and to the journal Environmental Health Perspectives for permission to adapt the contents of Table 1 of Kosnett and others (2007) for the present Fig. 3.

\section{References}

Alt, B.T., R.M. Koerner, D.A. Fisher and J.C. Bourgeois. 1985 Arctic climate during the Franklin era, as deduced from ice cores. In: Sutherland, P.D. (editor). The Franklin era in $\mathrm{Ca}$ nadian Arctic history 1845-1859. Ottawa: National Museum of Man (Mercury Series, Archaeological Survey of Canada 131): 69-92.

Amy, R., R. Bhatnagar, E. Damkjar and O. Beattie. 1986. The last Franklin expedition: report of a post-mortem examination of a crew member. Canadian Medical Association Journal 135 (July): 115-117.

Anderson, R. 1855. Sick list of HMS Enterprise, 14 December 1849 to 24 May 1855. London: National Archives Admiralty Records:ADM 101/99/5.

Armstrong, A. 1853. Sick list of HMS Investigator, 1 January 1850 to 3 June 1853. London: National Archives. Admiralty Records:ADM 101/250.

Armstrong, A. 1857. A personal narrative of the discovery of the north-west passage. London: Hurst and Blackett.

Attwood, M. 1995. Strange things: the malevolent north in Canadian literature. Oxford: Clarendon Press.

Baker, E.L., R.G. Feldman, R.A. White, J.P. Harley, C.A. Niles, G.E. Dinse and C. Berkey. 1982. Occupational lead toxicity: a behavioural and electrophysiological evaluation. British Journal of Industrial Medicine 41: 352-361.

Barbosa, Jr., F., J.E. Tanus-Santos, R.F. Gerlach and P.J. Parsons. 2005. A critical review of biomarkers used for monitoring human exposure to lead: advantages, limitations and future needs. Environmental Health Perspectives 113 (12): 1669-1674.

Battersby, W. 2008. Identification of the probable source of the lead poisoning observed in members of the Franklin expedition. Journal of the Hakluyt Society. September 1-10. URL: http://www.hakluyt com

Battersby, W. and P. Carney. 2011. Equipping HM Ships Erebus and Terror, 1845. International Journal for the History of Engineering and Technology 81: 159-180.

Beattie, O. 1985. Elevated bone lead levels in a crewman from the last Arctic expedition of Sir John Franklin. In: Sutherland, P.D. (editor). The Franklin era in Canadian Arctic history 1845-
1859. Ottawa: National Museum of Man (Mercury Series, Archaeological Survey of Canada 131): 141-148.

Beattie, O. and J. Geiger. 1987. Frozen in time: the fate of the Franklin expedition. London: Bloomsbury.

Beattie, O.W. and J.M. Savelle. 1983. Discovery of human remains from Sir John Franklin's last expedition. Historical Archaeology 17: 100-105.

Bell, B. 1881. Lieut. John Irving R.N. of H.M.S. "Terror" in Sir John Franklin's last expedition to the Arctic regions. A memorial sketch and letters. Edinburgh: David Douglas.

Bleeker, M., K.N. Lindgren and D.P. Ford. 1997. Differential contribution of current and cumulative indices of lead dose to neuropsychological performance by age. Neurology 48: 639645.

Bleeker, M., D.P. Ford, M.A. Celio, C.G. Vaughan and K.N. Lindgren. 2007. Impact of cognitive reserve on the relationship of lead exposure and neurobehavioral performance. Neurology 69: 47-476.

Bradford, A.R. 1851. Sick list of HMS Resolute, 28 February 1850 to 9 October 1851. London: National Archives Admiralty Records ADM 101/117/3.

Brandt, A. 2011. The man who ate his boots: Sir John Franklin and the tragic history of the northwest passage. London: Jonathan Cape.

Burnett, W. 1823. An account of the effect of mercurial vapours on the crew of His Majesty's Ship Triumph in the year 1810. Philosophical Transactions of the Royal Society 113: 402408.

Burton, H. 1840. A remarkable effect upon the human gums produced by the absorption of lead. Medico-Chirurgical Transactions 23: 63-79.

Cake, K.M. 1994. In vivo X-ray fluorescence of bone lead in the study of human lead metabolism. Unpublished M.Sc. thesis, Toronto: McMaster University, Department of Physics and Astronomy (cited by Keenleyside and others 1996).

Cavell, J. 2009. Going native in the north: reconsidering British attitudes during the Franklin search, 1848-1859. Polar Record 45: 25-35.

Cavell, J. 2013. Publishing Sir John Franklin's fate. Book History, in press.

Cheng, Y., W.C. Willett, J. Schwartz, D. Sparrow, S. Weiss and H. Hu. 1998. Relation of nutrition to bone lead and blood lead levels in middle-aged to elderly men. American Journal of Epidemiology 147 (12): 1162-1174.

Clarkson, T.W. and L. Magos. 2006. The toxicology of mercury and its chemical compounds. Critical Reviews in Toxicology 36: 609-692.

Curtin, P.D. 1989. Death by migration. Cambridge: Cambridge University Press.

Cyriax, R.J. 1939. Sir John Franklin's last Arctic expedition: a chapter in the history of the Royal Navy. Plaistow and Sutton Coldfield: Arctic Press (1997 reprint of the 1939 edition).

Cyriax, R.J. 1947. A historic medicine chest. Canadian Medical Association Journal 57: 295-300.

Cyriax, R.J. 1969. The unsolved problem of the Franklin expedition records supposedly buried on King William Island. Mariner's Mirror 55: 23-32.

Dawson, E.B., D.R. Evans, W.A. Harris, M.C. Teter and W.J. McGanit. 1999. The effect of ascorbic acid supplementation on the blood lead levels of smokers. Journal of the American College of Nutrition 18 (2): 166-170.

Doherty, M.J. 2004. The quicksilver prize. Mercury poisoning aboard HMS Triumph and HMS Phipps. Neurology 62: 963966.

Dorsey, C.D., B.K. Lee, K.I. Bolla, V.M. Weaver, S.S. Lee, A.C. Todd, W. Shi and B.S. Schwartz. 2006. Comparison 
of patella lead with blood lead and tibia lead and their associations with neurobehavioral test scores. Journal of Environmental Medicine 48 (5): 489-496.

Eber, D.H. 2008. Encounters on the passage: Inuit meet the explorers. Toronto: University of Toronto Press.

Elliotson, J. 1839. The principles and practice of medicine .Vol. II. London: Joseph Butler.

Farrer, K.T.H. 1993. Lead and the last Franklin expedition. Journal of Archaeological Science 20: 399-409.

Galwey, N.W. 2006. Introduction to mixed modelling: beyond regression and analysis of variance. Chichester: Wiley.

Gordon, J.N., A. Taylor and P.N. Bennett. 2002. Lead poisoning: case studies. British Journal of Clinical Pharmacology 53: 45-458.

Grandjean, P., E. Arnvig and J. Beckmann. 1978. Psychological dysfunctions in lead-exposed workers. Scandinavian Journal of Work Environment and Health 4: 295-303.

Hänninen, H., A. Aitio, T. Kovola, R. Luukonen, E. Matikainen, T. Mannelin, J. Erkkilä and V. Riihimäki. 1997. Occupational exposure to lead and neuropsychological dysfunction. Occupational and Environmental Medicine 55: 202-209.

Hansen, T. 2010. Additional documents and survey on the Franklin sites of Beechey Island, Nunavut, Canada. Polar Record 46 (238): 193-199.

Health and Safety Executive. 2012. Lead and you. URL: www.hse.gov.uk/pubns/indg305.pdf

Healy, N., D.R. Chettle, F.E. McNeill and D.E.B. Fleming. 2008. Uncertainties in the relationship between tibia lead and cumulative blood lead index. Environmental Health Perspectives 116: A109.

Hernberg, S. 2000. Lead poisoning in a historical perspective. American Journal of Industrial Medicine 38: 244-254.

Hie, H., H. Hu and D.R. Chettle. 2008. Application and methodology of in vivo $\mathrm{K} x$-ray fluorescence of $\mathrm{Pb}$ in bone (impact of KXRF data in the epidemiology of lead toxicity, and consistency of the data generated by updated systems). X-Ray Spectroscopy 37: 69-75.

His Majesty's Stationery Office. 1835. Regulations and instructions for the medical officers of his majesty's fleet. London: W. Clowes.

Hooper, R. 1839. Lexicon medicus (7th edn). London: Longman and Orme.

Hsieh, T.-Y., Y.-C. Chen, C.-W. Li, Y.-W. Chiu and H.-Y. Chuang. 2009. A proton magnetic resonance spectroscopy study of the chronic lead effect on the basal ganglia and frontal occipital lobes in middle-age adults. Environmental Health Perspectives 117 (6): 941-945.

Hu, H., M. Payton, S. Komck, A. Aro, D. Sparrow, S.T. Weiss and A. Rotnitzky. 1996. Determinants of bone and blood lead levels among community-exposed middle-aged to elderly men. American Journal of Epidemiology 144: 749-759.

Hu, H., R. Shih, S. Rothenberg and B.S. Schwartz. 2007. The epidemiology of lead toxicity in adults: measuring dose and consideration of other methodologic issues. Environmental Health Perspectives 115 (3): 455-462.

Kane, E.K. 1856. The U.S. Grinnell expedition in search of Sir John Franklin: a personal narrative. Philadelphia: Childs and Peterson.

Keenleyside, A., X. Song, D.R. Chettle and C.E. Webber. 1996. The lead content of human bones from the 1845 Franklin expedition. Journal of Archaeological Science 23: 461-465.

Keenleyside, A., M. Bertulli and H.C. Fricke. 1997. The final days of the Franklin expedition: new skeletal evidence. Arctic 50 (1): $36-46$.

Kosnett, M.J., R.P. Wedeen, S.J. Rothenberg, K.L. Hipkins, B.L. Materna, B.S. Schwartz, H. Hu and A. Woolf. 2007.
Recommendations for medical management of adult lead exposure. Environmental Health Perspectives 115 (3): 463471.

Kowal, W.A., P.M. Krahn and O.B. Beattie. 1989. Lead levels in human tissues from the Franklin Forensic Project. International Journal of Environmental and Analytical Chemistry 35: 119-126.

Kowal, W.F., O.W. Beattie, H. Baadsgaard and P. Krahn. 1991. Source identification of lead found in tissues of sailors from the Franklin expedition of 1845. Journal of Archaeological Science 18: 193-203.

Lambert, A. 2009. Franklin: tragic hero of polar navigation. London: Faber and Faber.

Lloyd-Jones, R. 2004. The Royal Marines on Franklin's last expedition. Polar Record 40 (215): 319-326.

Lloyd-Jones, R. 2005. The men who sailed with Franklin. Polar Record 41(219): 311-318.

Lloyd-Jones, R. 2011. Further light on Franklin's men. Polar Record 47: 379-382.

Lyall, D. 1854. Sick list of HMS Assistance, 16 February 1852 to 15 May 1854. London: National Archives Admiralty Records ADM 101/87/8.

McClintock, F.L. 1859. The voyage of the 'Fox' in the Arctic seas: a narrative of the discovery of the fate of Sir John Franklin and his companions. London: John Murray.

Markham, C.R. 1921. The lands of silence, a history of Arctic and Antarctic exploration. Cambridge: Cambridge University Press.

Martin, R.R., S. Naftel, S. Macfie, K. Jones and A. Nelson. 2013. $\mathrm{Pb}$ distribution in bones from the Franklin expedition: synchrotron $\mathrm{X}$-ray fluorescence and laser ablation/mass spectroscopy. Applied Physics A 111: 23-29.

Mays, S., A. Ogden, J. Montgomery, S. Vincent, W. Battersby and G.M. Taylor. 2011. New light on the personal identification of a skeleton of a member of Sir John Franklin's last expedition to the Arctic, 1845. Journal of Archaeological Science 38: 1571-1582.

Mays, S., G.J.R. Maat, and H.H. De Boer. 2013. Scurvy as a factor in the loss of the 1845 Franklin expedition to the Arctic: a reconsideration. International Journal of Osteoarchaeology DOI: 10.1002/oa.2305.

Milković-Kraus, S., N. Restek-Samaržija, M. Samaržija and O. Kraus. 1997. Individual variation in response to lead exposure: a dilemma for the occupational health physician. American Journal of Industrial Medicine 31: 631-635.

Millar, K., J.A.R. Nicoll, S. Thornhill, G.D. Murray and G.M. Teasdale. 2003. Long-term outcome after head injury: relation to APOE genotype. Journal of Neurology, Neurosurgery and Psychiatry 74:1047-1052.

Moore, M.R., S.J. Pocock, P.A. Meredith, I.M. Stewart, H. MacAnespie, R. Lees and R.A.L. Low. 1982. Some studies of maternal and infant lead exposure in Glasgow. Scottish Medical Journal 27: 113-123.

Moore, M.R. 1986. Sources of lead exposure. In: Lansdown, R. and W. Yule (editors). The lead debate: the environment, toxicology and child health. Beckenham: Croom Helm: 131192.

Needleman, H. 2004. Lead poisoning. Annual Review of Medicine 55: 209-222.

Notman, D.N.H., L. Anderson, O. Beattie, and R. Amy. 1987. Arctic paleoradiology: portable radiographic examination of two frozen sailors from the Franklin expedition (18451848). American Journal of Radiology 149 (August): 347350.

Oliveira, S., A. Aro and H. Hu. 2002. Season modifies the relationship between bone and blood lead levels: the normative 
aging study. Archives of Environmental Health 57 (5): 466472.

Onalaja, A.O. and L. Claudio. 2000. Genetic susceptibility to lead poisoning. Environmental Health Perspectives 108 (supplement 1): 23-28.

Owen, R. 1978. The fate of Franklin. The life and mysterious death of the most heroic of Arctic explorers. London: Hutchinson and Co.

Payton, M., K.M. Riggs, A. Spiro, S.T. Weis and H. Hu. 1998. Relations of bone and blood lead to cognitive function: the VA Normative Aging Study. Neurotoxicology and Teratology 20 (1): 19-27.

Pearce, J.M.S. 2007. Burton's line in lead poisoning. European Neurology 57: 118-119.

Pemberton, J. 2006. Medical experiments carried out in Sheffield on conscientious objectors to military service during the 1939-45 war. International Journal of Epidemiology 35: 556558.

Peters, J.L., M.G. Weissfopf, A. Spiro III, J. Schwartz, D. Sparrow, H. Nie, H. Hu, R.O. Wright and R.J. Wright. 2010. Interaction of stress, lead burden, and age on cognition in older men: the VA Normative Aging Study. Environmental Health Perspectives 118 (4): 505-510.

Philips, C. 1985. The camps, cairns and caches of the Franklin and Franklin search expeditions. In: Sutherland, P.D. (editor). The Franklin era in Canadian Arctic history 18451859. Ottawa: National Museum of Man (Mercury Series, Archaeological Survey of Canada 131): 149-173.

Pinheiro, J., D. Bates, S. DebRoy, D. Sarkhar and the R Development Core Team. 2013. nlme: Linear and nonlinear mixed effects models. $R$ package version 3.1-111.

Powell, B.D. 2006. The memorials on Beechey Island, Nunavut, Canada: an historical and pictorial survey. Polar Record 47 (223): 325-333.

Reed, B.R., D. Mungas, S. Tomaszewski Farias, D. Harvey, L. Beckett, K. Widaman, L. Hinton and C. DeCarli. 2010. Measuring cognitive reserve based on the decomposition of episodic memory variance. Brain 133: 2196-2209.

Robertson, J. 1849. Sick list of HMS Enterprise, 3 February 1848 to 26 November 1849. London: National Archives Admiralty Records ADM 101/99/4.

Rodrigues, J.L., B.L. Batista, J.A. Nunes, C.J.S. Passos and F. Barbosa Jr. Evaluation of the use of human hair for biomonitoring the deficiency of essential and exposure to toxic elements. Science of the Total Environment 405: 37376.

Sanders, T., Y. Liu, V. Buchner and P.B. Tchounwou. 2009. Neurotoxic effects and biomarkers of lead: a review. Reviews in Environmental Health 24 (1): 15-45.

Schwartz, B.S., B.-K. Lee, G.-P. Lee, W.F. Stewart, S.-S. Lee, K.-Y. Hwang, K.-D. Ahn, Y.-B. Kim, K.I. Bolla, D. Simin, P.J. Parsons and A.C. Todd. 2001. Associations of blood lead, dimercaptosuccinic acid-chelatable lead, and tibia lead with neurobehavioral test scores in South Korean lead workers. American Journal of Epidemiology 153 (5): 453464.

Schwartz, B.S., B.-K. Lee, K. Bandeen-Roche, W. Stewart, K. Bolla, J. Links, V. Weaver and A. Todd. 2005. Occupational lead exposure and longitudinal decline in neurobehavioral test scores. Epidemiology 16 (1): 106-113.

Schwartz, B.S., H. Hu, S.J. Rothenberg and A.C. Todd. 2008. Relationship between tibia lead and cumulative blood lead index: Schwartz et al. respond. Environmental Health Perspectives 116: A109-A110.
Scinicariello, F., A. Yesupriya, M.H. Chang and B. Fowler. 2010. Modification by $A L A D$ of the association between blood lead and blood pressure in the U.S. population: results from the Third National Health and Nutrition Examination Survey. Environmental Health Perspectives 118: 259-264.

Shih, R.A., T.A. Glass, K. Bandeen-Roche, M.C. Carlson, K.I. Bolla, A.C. Todd and B.S. Schwartz. 2006. Environmental lead exposure and cognitive function in community-dwelling older adults. Neurology 67: 1556-1562.

Shih, R.A., H. Hu, M.G. Weisskopf and B.S. Schwartz. 2007. Cumulative lead dose and cognitive function in adults: a review of studies that measured both blood lead and bone lead. Environmental Health Perspectives 115 (3): 483-492.

Simon, J.A. and E.S. Hudes. 1999. Relationship of ascorbic acid to blood lead levels. Journal of the American Medical Association 281 (24): 2289-2293.

Stefansson, V. 1939. Unsolved mysteries of the Arctic. London: G.G. Harrap and Co.

Stewart, W.F., B.S. Schwartz, D. Simon, K.I. Bolla, A,C. Todd and J. Links. 1999. Neurobehavioral function and tibial and chelatable lead levels in 543 former organolead workers. Neurology 52: 1610-1617.

Stewart, W.F., B.S. Schwartz, D. Simon, K. Kelsey and A.C. Todd. 2002. ApoE genotype, past adult lead exposure, and neurobehavioral function. Environmental Health Perspectives 110 (5): 501-505.

Stewart, W.F., B.S. Schwartz, C. Davatzikos, D. Shen, D. Liu, X. Wu, A.C. Todd, W. Shi, S. Bassett and D. Youssen. 2006. Past adult lead exposure is linked to neurodegeneration measured by brain MRI. Neurology 66: 1476-1484.

Sutherland, P.C. 1852. Journal of a voyage in Baffin's Bay and Barrow Straits, in the years 1850-1851. Vol. I. London: Longman, Brown, Green and Longman.

Thomson, A.T. 1822. The London dispensatory. A practical synopsis of materia medica, pharmacy and therapeutics (3rd edn). London: Longman, Hurst, Rees, Orme and Brown.

Troesken, W. 2006. The great lead water pipe disaster. Cambridge (Mass): MIT Press.

Turnbull, W. 1806. The naval surgeon; comprising the entire duties of professional men at sea. London: Richard Philips.

Virgiolini, M.B., K. Chen, D.D. Weston, M.R. Bauter and D.A. Cory-Slechta. 2005. Interactions of chronic lead exposure and intermittent stress: consequences for brain catecholamine systems and associated behaviors and HPA axis function. Toxicological Sciences 87: 469-482.

Watson, T. 1857. Lectures in the principles and practice of physic. Vol. II (4th edn). London: J.W. Parker and Son.

Weisskopf, M.G., R.O. Wright, J. Schwartz, A. Spiro III, D. Sparrow, A. Aro and H. Hu. 2004. Cumulative lead exposure and prospective change in cognition among elderly men. American Journal of Epidemiology 160 (12): 1184-1193.

Wilker, E., S. Korrick, L.H. Nie, D. Sparrow, P. Vokonas, B. Coull, R.O. Wright, J. Schwartz and H. Hu. 2011. Longitudinal changes in bone lead levels: the VA normative aging study. Journal of Occupational and Environmental Medicine 53 (8): 850-855.

Williams, G. 2010. Arctic labyrinth: the quest for the northwest passage. London: Penguin.

Wittmers, L.E., J. Wallgren, A. Alich, A.C. Aufderheide and G. Rapp. 1988. Lead in bone. IV. Distribution of lead in the human skeleton. Archives of Environmental Health 43 (6): 381-391.

Woodman, D.C. 1991. Unravelling the Franklin mystery: Inuit testimony. Montreal: McGill-Queen's University Press. 